\title{
Isabel of Aragon (d. I336): Model Queen or Model Saint?
}

\author{
by IONA MCCLEERY
}

Very little work has been done on Iberian queens and even less on Iberian saints. This study of Isabel of Aragon (c. I270-1336), wife of King Dinis of Portugal (1279-1325), who was venerated as a saint from shortly after her death, aims to explore the relationship between Isabel's queenship and her sainthood. It engages with recent research, and critiques obvious comparisons between Isabel and her great-aunt St Elizabeth of Thuringia. Isabel may also be compared with numerous other medieval European queens and her main vita displays striking similarities to royal courtesy literature found elsewhere.

$\mathrm{O}$ n 26 March i6r2 witnesses watched the opening of a tomb in the Franciscan nunnery of Santa Clara in Coimbra, Portugal. One of them later described the condition of the body found inside:

despite being nearly three hundred years old, the sainted body was whole, the face noble, the hair golden and still attached to the skin, the arm and right hand entire, the nails as if they were of a living person ... and in the features of the face there was great similarity to the effigy that we see on the tomb. ${ }^{1}$

Medical practitioners in attendance confirmed the body's lack of corruption; Gonçalo Dias, chief surgeon of Coimbra, remarked: 'I feel for certain that it is beyond natural order for a body to be so many years without decay, which can only be miraculous. ${ }^{2}$ Whose was this miraculous body and why did it arouse so much interest? The tomb was that of Isabel of Aragon, wife of King Dinis of Portugal (1279-I325), who had indeed died nearly three hundred years earlier on 4 July I336, and the tomb-opening was part of a long-drawn-out process that eventually led to her canonisation on 25 May i625. Known as the Rainha Santa, Isabel is venerated as Portugal's only officially canonised royal saint.

The cult of Isabel of Aragon first came to my attention in the context of wider research on the relationship between medicine and religion in late

1 A. G. Ribeiro de Vasconcelos, Evolução do culto de Dona Isabel de Aragão, esposa do rei lavrador Dom Dinis de Portugal ( a Rainha Santa), Coimbra I894, repr. 1993, ii. I 8. Translations throughout are my own unless otherwise indicated.

${ }^{2}$ Ibid. ii. I24. 
medieval Portugal. Physicians were involved in various aspects of Isabel's cult, as evidenced by the descriptions of her body in I6I2, and Isabel had attributed to her a number of healing miracles of medical interest. It became apparent that before much progress could be made on the medical aspects of the cult, it would be necessary to explore both the cult and Isabel's life in more detail. Hagiography has only relatively recently become a serious subject of investigation in Portugal, and there is very little interest in queenship. ${ }^{3}$ In contrast, these fields have developed elsewhere by leaps and bounds. Once scarcely studied at all, queens are now seen as powerful individuals with a major stake in the political process of their husbands' realms. ${ }^{4}$ Similarly the creation of royal saints' cults is now viewed as an intrinsic part of dynastic power-building, and the saints themselves represent a distinct form of medieval spirituality. ${ }^{5}$ It therefore seemed that the time was right to embark on a study of Isabel's sainthood and queenship, making use of new scholarship.

Applying this scholarship to a Portuguese queen has proved surprisingly difficult. The early fourteenth century is one of the least-known periods in Iberian history and the whole issue of Iberian sainthood is problematic. Historians argue that there was no tradition of sacral kingship similar to that which created royal cults elsewhere, and note that few Iberian saints were papally recognised during the Middle Ages. ${ }^{6}$ Further research reveals that Isabel of Aragon was far from being the only Portuguese royal saint, but if these monarchs lacked the quasi-sacral qualities of northern, that is English or French, monarchy - remaining largely uncrowned, unanointed and laying no claim to healing powers - how did they become saints? ${ }^{7}$ It is clear that much needs to be done on this subject. There has at least been some

${ }^{3}$ F. F. de la Figanière, Memorias das rainhas de Portugal: D. Teresa-Santa Isabel, Lisbon I859, has not been superseded. There are no proper biographies of Isabel or Dinis. S. R. Ackerlind, King Dinis of Portugal and the Alfonsine heritage, New York i99o, and Á. Muñoz Fernández, Mujery experiencia religiosa en el marco de la santidad medieval, Madrid I988, come closest.

${ }^{4}$ J. C. Parsons (ed.), Medieval queenship, Stroud i994; A. J. Duggan (ed.), Queens and queenship in medieval Europe, Woodbridge 1997.

5 A. Vauchez, Sainthood in the later Middle Ages, trans. J. Birrell, Cambridge 1997, 177-83, $226-32$.

6 T. F. Ruiz, 'Unsacred monarchy: the kings of Castile in the late Middle Ages', in S. Wilentz (ed.), Rites of power: symbolism, ritual and politics since the Middle Ages, Philadelphia I999, Io9-44; R. Costa Gomes, The making of a court society: kings and nobles in late medieval Portugal, Cambridge 2003, 370-90; N. Jaspert, 'Heresy and holiness in a Mediterranean dynasty: the house of Barcelona in the thirteenth and fourteenth centuries', in D. A. Agius and I. R. Netton (eds), Across the Mediterranean frontiers: trade, politics and religion, 650-I450, Turnhout I997, IO5-35.

7 Other Portuguese royal saints were King Afonso Henriques (d. I185); Teresa (d. I250), Mafalda (d. 1256) and Sancha (d. I229), daughters of Sancho I; the Principe Santo Fernando (d. I443), son of João I; and the Infanta Santa Joana (d. I490), daughter of Afonso V. 
important comparative work on Iberian queenship that should encourage future investigations. ${ }^{8}$

The aim here is to explore the relationship between Isabel's queenship and sainthood, engaging critically with some of the research that has been done in recent years. The two historians whose work is particularly relevant are Gabor Klaniczay, who studies the saintly princesses of central Europe, and Jo Ann MacNamara, who has explored the careers of early medieval saint-queens. ${ }^{9}$ The career of Isabel of Aragon is rarely considered outside the Iberian peninsula, passing only fleetingly through some of the literature, ${ }^{\mathbf{1 0}}$ yet she is an example of queenly sainthood from a later period than that studied by MacNamara, and she offers a parallel perspective from a different part of Europe to that studied by Klaniczay. An exploration of Isabel's life and cult provides an opportunity to examine current ideas on queenship and sainthood using a less well-known figure as a kind of litmus test.

Isabel was born in c. I270 to Pere III of Aragon (Pere II of Catalonia) and Constance Hohenstaufen (see Figures 7, 8 below). Through her father she was a great-niece of Elizabeth of Hungary or Thuringia (d. I23I), one of the most influential saints of the late Middle Ages. In 128I/2 Isabel married Dinis of Portugal. Although his reign is often viewed as the high point of the Portuguese Middle Ages, it was marred by civil war in I319-23 between Dinis and his favoured illegitimate son Afonso Sanches on the one side, and Isabel and her son, the future Afonso IV (I325-57), on the other. It is usually said that consequently Isabel's was an unhappy marriage. The couple had two children: Afonso (born I29I) and Constança (born I290), the latter marrying Fernando IV of Castile (I295-I3I2) in I302 and dying shortly after him in I3I3, leaving a baby son Alfonso XI (I3I2-50). The successive minorities experienced by Castile during this period

8 T. M. Vann, 'The theory and practice of medieval Castilian queenship', in T. M. Vann (ed.), Queens, regents and potentates, Dallas I993, I25-47; M. Shadis, 'Piety, politics and power: the patronage of Leonor of England and her daughters Berenguela of León and Blanche of Castile', in J. Hall McCash (ed.), The cultural patronage of medieval women, Athens, GA I996, 202-27, and 'Berenguela of Castile's political motherhood: the management of sexuality, marriage and succession', in J. C. Parsons and B. Wheeler (eds.), Medieval mothering, New York I996, 335-58; A. Echevarria, 'Catalina of Lancaster, the Castilian monarchy and coexistence', in R. Collins and A. Goodman (eds), Medieval Spain: culture, conflict and coexistence: studies in honour of Angus MacKay, Basingstoke 2002, 79-122; Costa Gomes, Making of a court society, 57-74. An important addition to scholarship is T. Earenfight (ed.), Queenship and political power in medieval and early-modern Spain, Aldershot 2005.

${ }^{9}$ G. Klaniczay, Holy rulers and blessed princesses: dynastic cults in medieval central Europe, trans. E. Pálmai, New York 2002; J. A. McNamara, 'Imitatio Helenae: sainthood as an attribute of queenship', in S. Sticca (ed.), Saints: studies in hagiography, Binghampton, NY 1996, 51-80.

10 Klaniczay, Holy rulers, 235, 326, 370; R. Folz, Les Saintes Reines du moyen âge en occident (VIe-XIIIe siècles), Brussels I992, I45-58; R. Kieckhefer, Unquiet souls: fourteenth-century saints in their religious milieu, Chicago-London I984, 54-6, 86, I29, I4I. 
allowed Dinis to develop a hegemonic position amongst Iberian monarchs, a process in which Isabel was actively involved. From her surviving letters to her brother Jaume II of Aragon (I285-1327), we know that Isabel arranged marriages, intervened in legal cases and occupied herself with her family in Castile, Aragon and Portugal. A few days before Dinis died in January I325, Isabel declared that she would not be buried next to him in his Cistercian foundation near Lisbon, but would lie in her own Franciscan foundation of Santa Clara in Coimbra. On 8 January, the day after Dinis died, Isabel took the Franciscan habit (though she did not profess as a nun) and devoted the rest of her life to Santa Clara. She seems to have lived in retirement there as a widow, so it is surprising that on 4 July 1336 death found her many miles away in Estremoz near the border with Castile, perhaps involved in negotiations between Afonso IV of Portugal and Alfonso XI of Castile. ${ }^{11}$

Isabel's body was brought back to Santa Clara for burial and within days miracle cures were reported. A Franciscan inquiry was set up to investigate them, and the state of Isabel's body, which had not decomposed despite the journey across the hot Alentejo plains. Both in 1336 and later in I6I2 when Isabel's tomb was opened, the preservation of her corpse would count as evidence for her sanctity. The historian luckily has access to one of the original notarial documents pertaining to this early inquiry. ${ }^{12}$ Otherwise, though, we are dependent on Isabel's main vita, which survives only in a late sixteenth-century copy belonging to Santa Clara of an early fifteenth-century copy of the original written in $c$. I340. ${ }^{13}$ This vita is accepted as genuine and, although it is anonymous, is usually attributed to Salvado Martins OFM, bishop of Lamego, one of Isabel's executors, who appears to have headed the inquiry into her miracles. ${ }^{14}$

11 N. Pizarro Dias, 'Dinis e Isabel, uma difícil relação conjugal e política', Revista portuguesa de história xxxi (1996), I29-65; Rainha Santa: cartas inéditas e outras documentos, ed. S. Antunes Rodrigues, Coimbra I958; V. A. Álvarez Palenzuela, 'Relaciones peninsulares en el siglo de Alcañices (1250-1350): regencias y minorías regias', Revista da faculdade de letras da universidade do Porto: história 2nd ser. xv (1998), I045-70; J. Mattoso, 'A guerra civil de I319-24', in J. Mattoso, Portugal medieval: novas interpretações, Lousã 1992, 293-308; F. F. Lopes, 'Santa Isabel de Portugal: a larga contenda entre el-rei D. Dinis e seu filho D. Afonso', Colectânea de estudos and ser. iv (I953), 3-4I, and 'Data e circunstância do casamento da Rainha Santa Isabel', Itinerarium ix (1963), 193-219.

12 P. de Azevedo, 'Inquirição de I336 sobre os milagres da Rainha D. Isabel', Boletim da segunda classe da Academia das Sciências de Lisboa iii (1910), 294-303.

${ }_{13}$ Modern editions are by J. J. Nunes, 'Vida e milagres de Dona Isabel, rainha de Portugal, Boletim da segunda classe da Academia das Sciências de Lisboa xiii (I918-I9), I293-384, and M. I. da Cruz Montes, 'Vida e milagres de Dona Isabel, rainha de Portugal (edição e estudo)', unpubl. MA diss. Universidade Nova, Lisbon i999. The Bollandists' Latin translation is used here: Acta sanctorum, ed. J. Bolland and G. Henschen, new edn J. Carnandet (hereinafter cited as Vita), Paris I863-, July II, I69-2I3.

${ }_{14}$ See Isabel's second will of I327: Vasconcelos, Evolução, ii. I5; Vita, I93-4. 


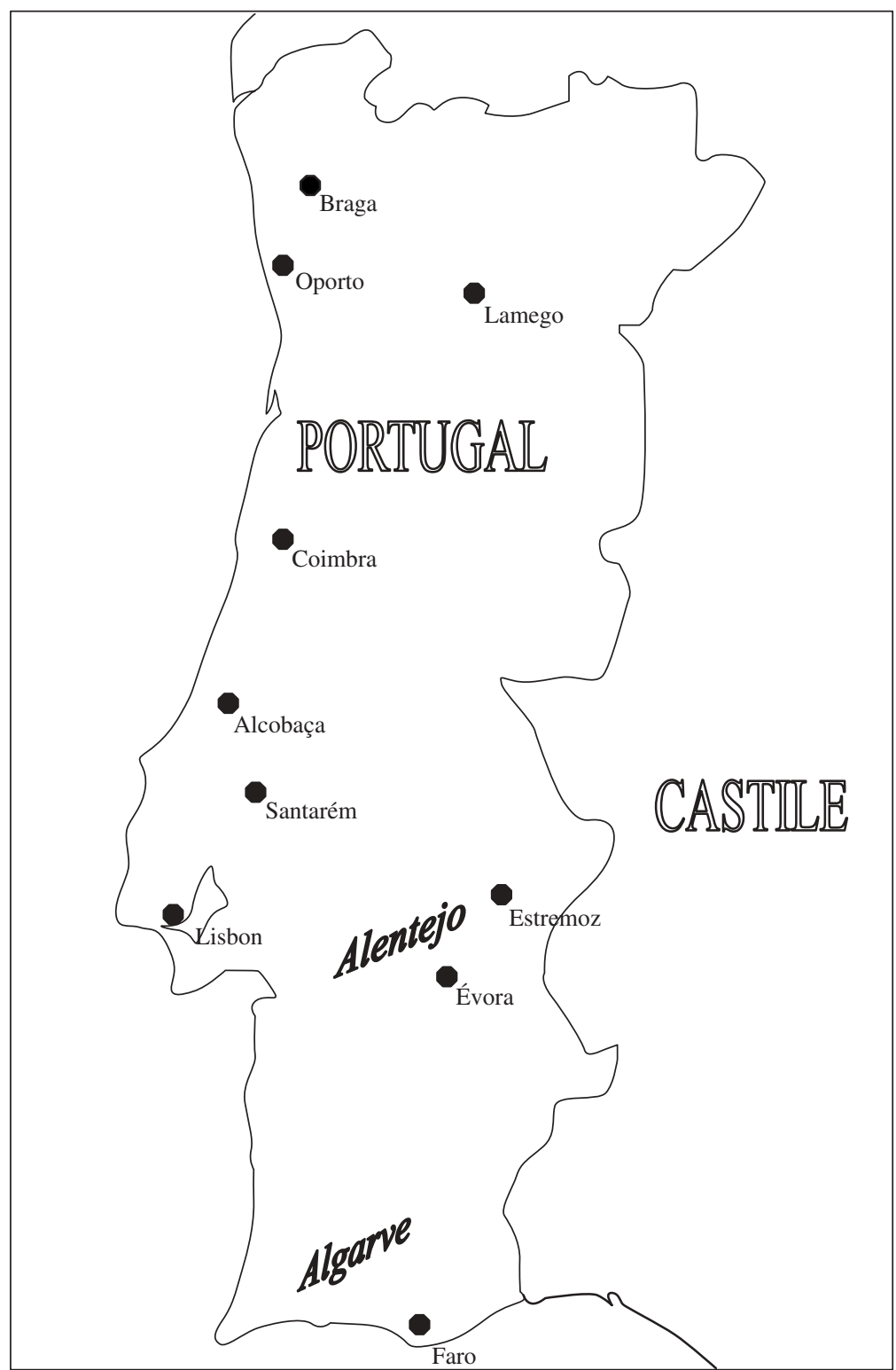

Figure I. Portugal in the fourteenth century.

It is equally possible that Isabel's niece Isabel de Cardona, abbess of Santa Clara and another executor involved in the inquiry, wrote the work. The author emphasises Isabel's Aragonese connections suggesting that he or she was closely connected to the Aragonese royal 


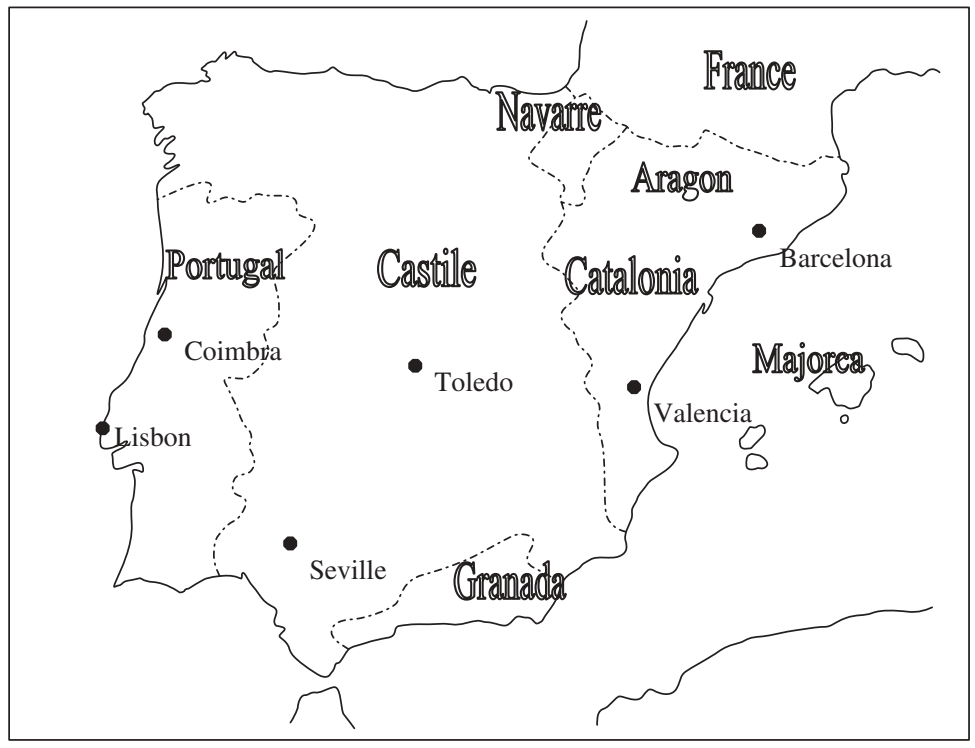

Figure 2. Portugal and the Iberian peninsula in the fourteenth century.

family. ${ }^{15}$ Genealogical lists are a key feature of this text, but it also records Isabel's charitable foundations and her involvement in the civil war and other political events. It presents an apparently accurate picture of Isabel's life, emphasising her lineage, her charity and her intercessory political acts as integral to her sainthood. ${ }^{\mathbf{1 6}}$

As well as the main vita, there are also a number of fifteenth- and sixteenthcentury chronicles and divine offices that include biographical material, and a shorter vita attributed to the chronicler Damião de Gois (d. I574).

15 Isabel left money to her niece in her will and designated the abbess of Santa Clara ex officio as one of her executors; Isabel de Cardona was abbess from 1329 to 1362 . See Vasconcelos, Evolução, i. 229-3I; ii. 6, I5, and H. David, A. Barros and J. Antunes, 'A família Cardona e as relações entre Portugal e Aragão durante o reinado de D. Dinis', Revista da faculdade de letras da universidade do Porto: história 2nd ser. iv (I987), 69-87. I hope to discuss the thorny issue of authorship elsewhere.

16 Nunes, 'Vida e milagres', divided the vita into the following chapters: I, 3-6: childhood, marriage, journey to Portugal; 7-(I3): early years of marriage, children, husband's infidelities, intervention in dispute between Dinis and brother, involvement in arbitration of CastilianAragonese conflict, son's marriage; I4-I6: civil war; I7-22: charitable activity during marriage; 23-3I, 33: widowhood, pilgrimage to Santiago de Compostela, construction of Santa Clara, liturgical routine, later charitable work; 34, 36: death and corpse's journey to Coimbra; 2, 32, 35: genealogy; 37-45: eight miracles recorded in $1336 ; 46$ : miracle dated I337; 47-51: five in vita miracles; 52-8: six posthumous miracles. The Bollandists divided the same material into thirteen chapters comprising one hundred and thirty-one sections. I hope to deal with this problematic structure elsewhere. 
The relationships between these works and the main vita require thorough analysis that cannot be carried out here, but it is worth noting that one of the offices and the short vita were both dedicated to Queen Caterina (d. ${ }^{5} 578$ ), sister of the Emperor Charles V and wife of João III of Portugal (I52I-57); relevant when assessing the long-term influence of Isabel's cult. ${ }^{17}$

The title to this paper seems to establish a dichotomy between model queenship and model sainthood, whereas historians usually view them as closely related ideals. For example, it is clear from medieval iconography and literature that the perfect queen and the perfect female saint throughout this period was the Virgin Mary, and that in official documents and hagiographical writings numerous women articulated their identities, powers and aspirations, or had them articulated for them, with reference to Marian imagery. ${ }^{18}$ It is also undeniable that some of the earliest female saints (after the martyrdoms of the early Church) were royal wives, like Bertha of Kent or Clotilde of Merovingian Gaul, who were able to intercede successfully between their pagan husbands and Christian missionaries, and that throughout the Middle Ages queens appear to have practised charity and interceded politically in increasingly ritualised ceremonies in imitation of these earlier models. This is the theory put forward by Jo Ann MacNamara, amongst others, who argues that sainthood thus became an attribute of queenship, although the idea does leave threads hanging. ${ }^{19}$ First in that MacNamara's model saint-queen died out in the mid-thirteenth century, as Christendom ceased to expand and absorb non-Christian peoples, which leaves Isabel of Aragon high and dry. ${ }^{20}$ Second, the model does not recognise that intercession was an active role of queens long before Christianity, as attested by the biblical figure of Esther, often used prior to the thirteenth century in preference to Marian images of queenly authority. ${ }^{21}$ Queenliness and saintliness are therefore not such obvious companions as one might think, and their early relationship demands further investigation.

There is here a gender relationship peculiar to a particular time in history. There were very few female saints in the early Middle Ages and most of them

17 Crónica de Portugal de I419, ed. A. de Almeida Calado, Aveiro 1998, I64-9, usually attributed to Fernão Lopes (d. c. I459); Rui de Pina (d. I522), Crónicas, ed. M. Lopes de Almeida, Oporto I977, I7-31, 378-9; 'Lenda da rainha D. Isabel (códice iluminado 223 da Biblioteca Nacional)', ed. T. Andrade e Sousa, Revista da Biblioteca Nacional 2nd ser. ii (1987), 23-48; Vasconcelos, Evolução, ii. 36-42, 45-57.

18 J. C. Parsons, 'The queen's intercession in thirteenth-century England', in J. Carpenter and S. B. Maclean (eds), Power of the weak: studies on medieval women, Chicago I995, I47-77.

19 MacNamara, 'Imitatio Helenae'. See also J. C. Parsons, 'Ritual and symbol in the English medieval queenship to I500', in L. O. Fradenburg (ed.), Women and sovereignty, Edinburgh I992, 6o-77.

${ }^{20}$ MacNamara, 'Imitatio Helenae', 79.

${ }^{21}$ L. L. Huneycutt, 'Intercession and the high-medieval queen: the Esther topos', in Carpenter and Maclean, Power of the weak, I26-46. 
were either queens or abbesses of royal stock. The only married women who achieved sainthood before the late Middle Ages were queens. Even when the situation changed later, encouraging veneration of married lower status women like Bridget of Sweden (d. I373) or Dorothy of Montau (d. I394), there continued to be an ambivalence towards chastity and child-bearing, an ambivalence that queens, whose main function was to produce an heir, to some extent escaped. In order to achieve sainthood an individual had to have a certain amount of visibility in society, ${ }^{22}$ and also, in accordance with the seminal ideas of Peter Brown concerning the holy man, had to be in a liminal position within a community yet also be a figure of power able to intercede between the community and the outside world. There has been some debate over whether these ideas can be applied to holy women, but certainly the only visible women were queens or royal abbesses in the early Middle Ages, and queens in particular, often as foreigners of a different faith in their husband's courts, certainly fulfilled Brown's criteria for holy intercessors. ${ }^{23}$ It might be more accurate to argue that instead of sainthood being an attribute of queenship, hagiographers and others saw queenship as an integral part of sainthood. Queens were simply more likely to become saints than other women. However, although most European queens appear to have behaved in similar ways throughout the Middle Ages relatively few became saints. Why this was the case? Did queens aspire to be saints or good queens? How were they viewed by their contemporaries and by subsequent generations: why were some queens remembered as saints, and others as Jezebels? It is generally understood that political, social and geographical factors have as much to do with sainthood as does behaviour, but it is not clear whether this understanding has been applied to the saint-queen. The argument presented here is that since there were few saint-queens in medieval Europe, but many queens, all requiring training and advice of some kind, there was surely a model of good queenship that need not have anything at all to do with sainthood.

There were only a few guides to queenship circulating in medieval Europe. ${ }^{24}$ The Siete partidas of Alfonso x of Castile, a law code compiled in the I26os, is rather limited in its description of the queen's role. It describes the selection of the king's wife and his relationship with her, placing great emphasis on her lineage and good habits, her role in the education and

${ }^{22}$ J. Tibbetts Schulenburg, 'Female sanctity: public and private roles, c. 500-1100', in M. Erler and M. Kowaleski (eds), Women and power in the Middle Ages, Athens, GA I988, I02-25.

${ }^{23} \mathrm{P}$. Brown, 'The rise and function of the holy man in late antiquity', Fournal of Roman Studies lxi (I97I), 80-IOI, and 'The rise and function of the holy man in late antiquity, I97I-I997', Fournal of Early Christian Studies vi (I998), 353-76; A. Cameron, 'On defining the holy man', in J. Howard-Johnston and P. A. Hayward (eds), The cult of saints in late antiquity and the Middle Ages: essays on the contribution of Peter Brown, Oxford I999, 28-43.

24 D. Bornstein, The lady in the tower: medieval courtesy literature for women, Hamden, CT I983, $76-93$. 
marriages of her children, and the duties of her husband's subjects towards her. The only advice on religious behaviour is the recommendation that princesses learn to read the Hours and the Psalter. ${ }^{25}$ Another key work is Christine de Pizan's Treasure of the city of ladies written in $\mathrm{I}_{4} \mathrm{O} 5$ as a guide for the young bride of the French dauphin. Here the princess is supposed to nurture the good-will of her husband's people, keep the peace and not take sides in disputes, take care of her husband's physical and spiritual health, even if he has affairs, dispense charity in secret, keep women of good repute around her, take pains with her children's education and work hard to support the heir once widowed. ${ }^{26}$ Notably, Christine believed that Elizabeth of Hungary was a saint in spite of her queenly status not because of it. A pious princess could become a saint but it was not the goal of her career and certainly not an attribute of her royal status; most queens would be lucky even to get into heaven in Christine's view. ${ }^{\mathbf{2 7}}$

It is clear from a brief summary of these two texts that the life of the ideal queen was similar in many ways to the life of Isabel of Aragon as recorded in her vita. Since the Siete partidas was known in Portugal and Isabel's husband Dinis consciously modelled himself on his grandfather Alfonso x, it is possible that this legal code influenced Isabel. ${ }^{28}$ As for Christine de Pizan's work, although it obviously could not have influenced Isabel herself, it is uncanny how close Christine's advice is to Isabel's experience. Subsequently, the Treasure of the city of ladies became well-known in Portugal after another Isabel (d. I472), daughter of João I (I385-I433), admired the work when she became duchess of Burgundy in I430, and sent it to her niece, also Isabel, queen of Portugal (d. I455), who had it translated into Portuguese. It was eventually

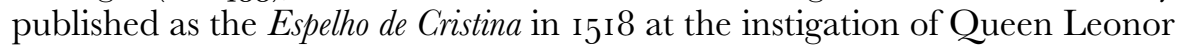
(d. I525), widow of João II $\left(\mathrm{I}_{4} 8 \mathrm{I}-95\right) \cdot{ }^{\mathbf{2 9}}$ There is thus firm evidence that this courtesy manual influenced Portuguese royal women, though it is not yet possible to show whether early-modern queens were aware of the similarities between the Espelho and the Isabelline hagiography also produced in a royal context in the mid-sixteenth century.

Part of the problem with these texts is that there are not enough comparative studies of Iberian and northern queenship or sainthood to allow more accurate judgement of Isabel's activity. Two possible avenues will be explored here. First, comparison will be made between Isabel of Aragon and

25 Vann, 'Theory and practice of medieval Castilian queenship', I26-7; Alfonso x, Las siete partidas, trans. S. P. Scott, ed. R. I. Burns, Philadelphia 2001, i. 298-308.

${ }^{26}$ C. de Pizan, Treasure of the city of ladies or the book of the three virtues, Harmondsworth 1985 , 47-IO5. $\quad 27$ Ibid. 36-46. $\quad{ }^{28}$ Ackerlind, Dinis of Portugal, 34-5.

${ }^{29}$ R. B. Bernard, 'The intellectual circle of Isabel of Portugal, duchess of Burgundy, and the Portuguese translation of Le Livre des trois vertus (O liuro dos tres vertudes)', in G. K. McLeod (ed.), The reception of Christine de Pizan from the fifteenth through the nineteenth centuries: visitors to the city, Lampeter I99I, 43-58. 
other queens of the period, in order to ascertain whether there was a form of queenly behaviour that transcended time and space and fed into the models found in the written works. Second, comparison will be made between Isabel and the most influential female royal saints of the period, those of Hungary studied by Klaniczay. If there were a model of saintly behaviour followed by Isabel and/or her hagiographer then we would expect to find it coming from this direction.

Since Isabel of Aragon was the great-niece of St Elizabeth of Hungary, it is easy to assume that she modelled herself on her kinswoman and aspired to join the wider Hungarian pantheon of saints. Indeed, Hungarian observers readily included Isabel in this blessed company. In I307 the bishop of Zagreb gave a speech to the Hungarian nobility in favour of the candidature to the Hungarian throne of the Angevin prince Charles Robert (d. 1342), descendant like Isabel of Andrew II of Hungary, in which he argued that Charles's right to the throne was based on his saintly lineage. He listed Elizabeth of Hungary, Isabel of Aragon, Margaret (d. 1270) and Cunegond (d. I292) (Elizabeth of Hungary's saintly nieces), Louis of Anjou, Franciscan bishop of Toulouse (d. I297) and Louis IX of France (d. I270), as the most important of the many saints found in the late medieval Hungarian-Capetian dynastic network. ${ }^{30}$ Hungarian historians have recently cast doubts on the authenticity of this speech, not least because Isabel of Aragon was still alive in I307. ${ }^{31}$ However, it is an indication that at some point Isabel was recognised as belonging to the Hungarian saints' 'club'.

The problem is that we need to understand Isabel within an Iberian context, not a Hungarian one. Undoubtedly Isabel's hagiographer was aware of some of these northern saints since he or she claimed that Isabel had been named after her great-aunt, and also referred to her kinship with Louis of Toulouse. ${ }^{32}$ There is no mention though of other Hungarian saints, nor of Louis IX of France, despite the fact that he was first cousin to Isabel's fatherin-law, Afonso III of Portugal. It is not clear whether Isabel's relationship to Elizabeth and Louis was meant to be dynastic, saintly or indeed Franciscan. Elizabeth is usually seen as a Franciscan saint, although she had no real affiliation to any religious order during her lifetime; Louis gave up the Angevin kingship in order to become a friar; and Isabel supported the Franciscans in a country where royal patronage usually focused on the Cistercians. Since Isabel's cult developed in a Franciscan context, this theory has weight. On the other hand, the vita has a strongly dynastic flavour, including lists of Isabel's relatives that have much more to do with Aragon

30 Klaniczay, Holy rulers, 324-5.

31 Ibid.; cf. idem, The uses of supernatural power: the transformation of popular religion in medieval and early-modern Europe, trans. S. Singerman, ed. K. Margolis, Oxford I990, I13-I4, 22I n. 9.

32 Vita, I73. 
than with Portugal. For example, Dinis's grandfather, Alfonso x of Castile, appears because he married Isabel's aunt Violant, he helped Jaume I 'the Conqueror' of Aragon conquer Murcia from the Moors and he was the son of Fernando III of Castile 'who conquered Seville'. ${ }^{33}$ Louis of Toulouse was mentioned because Isabel's sister Violant married his brother Robert of Naples. Portuguese royal saints, such as Dinis's own great-aunt Teresa, have no place at all in the vita, suggesting that sainthood as such was not the model followed here ${ }^{34}$ Lineage probably was a key element in Isabel's sainthood, but it was an especial Iberian dynastic mystique built on conquest and personal prestige, not on kinship to other European saints.

Turning to Isabel's pious behaviour in her vita, there do appear to be similarities between her life and that of Elizabeth of Hungary. ${ }^{35}$ It can be argued that to some extent their behaviour is partly formulaic, knowingly based around the Seven Acts of Mercy. It is not necessarily the case that Isabel was imitating Elizabeth; both women could have been conforming to a standard model of piety that informed the charitable work of numerous European women, and men, who supported religious houses and provided poor relief. It is also recognised that hagiographers copied motifs from one saint's life to another. Isabel's most famous miracle, in which her charitable giving is concealed from her husband by alms turning into roses, cannot be found before the sixteenth century and derives from an apocryphal story told about Elizabeth from the second half of the thirteenth century. ${ }^{36}$ There are further parallels between the lives of Isabel and Elizabeth. Both women were foreigners in their husbands' lands and suffered periods of dispossession and exile. They were wives and mothers who endeavoured to lead pious lives while married but were liberated by widowhood. However, these similarities are outweighed by some significant differences. In contrast to Isabel, Elizabeth had a loving relationship with her husband, though she later rejected her children, and she engaged in a variety of mystical and selfmortifying acts under the guidance of her harsh spiritual advisor Conrad of

33 Ibid. I73, I74, I89.

34 B. K. Lackner, 'A Cistercian of royal blood: Bl. Teresa of Portugal', Vox Benedictina vi (I989), I00-і9.

${ }_{35}$ Limited information on Iberian royal libraries means we cannot prove that Isabel was familiar with Elizabeth's most popular vita found in The Golden Legend: readings on the saints, trans. W. Granger Ryan, Princeton 1993, ii. 302-18. See I. Michael, 'Medieval Spanish royal libraries and their dispersal', in A. Deyermond and J. Lawrance (eds), Letters and society in fifteenth-century Spain: studies presented to P. E. Russell on his eightieth birthday, Llangrannog I993, IO3-I3.

${ }_{36}$ Vasconcelos, Evolução, i. I44-5, 423-4; Klaniczay, Holy rulers, 369-72; A. Vauchez, 'L'Influence des modèles hagiographiques sur les représentations de la sainteté, dans les procès de canonisation (xIIIe-xve siècle)', in E. Patlagean and P. Riché (eds), Hagiographies: cultures et sociétés, Paris I98I, 585-96. Note too a reverse version of the story where Isabel hands out roses that later turn into cash, found in the short vita attributed to Damião de Gois: 'Lenda', 46. 
Marburg. ${ }^{37}$ Isabel certainly fasted regularly but there is no mention of extreme suffering, nor ecstatic states, apart from two visions. ${ }^{38}$ Isabel also remained very close to her children and does not appear to have had a specific spiritual advisor. Finally, the most important difference between these women was the political influence wielded by Isabel as queen. It is in this context that comparison between Isabel and the central European princesses studied by Klaniczay is less meaningful.

There is no consensus amongst historians as to what constituted queenly power and whether it increased or declined during the Middle Ages, but by whatever criteria one uses, Isabel of Aragon was a powerful figure in fourteenth-century Iberia. ${ }^{39}$ Few of the central European women studied by Klaniczay, on the other hand, were able to exercise much political power, and those who did usually suffered the consequences; Gertrude of Meran, St Elizabeth's mother, was murdered for her political interference in I2I3 ${ }^{40}$ Princesses like Elizabeth and her niece Margaret of Hungary were essentially powerless, whether this was the fate dealt out to them by fathers and brothers, or the result of their own submission to rigid spiritual regimes. Ironically, the saintly reputations this lifestyle created were indeed empowering, enabling some princesses later to intervene in dynastic disputes. ${ }^{41}$ The dynastic cults maintained by the descendants of these women were also politically powerful. ${ }^{42}$ All this suggests that comparison between royal saints from different parts of Europe has to take into account contrasting political systems, and differing relationships between spiritual and secular powers. Further comparison of the cults in question could be useful, but the Hungarian context should not be pursued to the detriment of the Portuguese.

If we focus on the Portuguese context, it does in fact become clear that Elizabeth meant something to Isabel. First, there is the evidence of Isabel's tomb in Santa Clara, designed according to her specifications as part of the construction work on the nunnery (see Figures 3-6). The tomb includes figures of St Elizabeth, St Catherine and St Clare at the foot and, on the

${ }^{37}$ A. Petrakopoulos, 'Sanctity and motherhood: Elizabeth of Thuringia', in A. B. MulderBakker (ed.), Sanctity and motherhood: essays on holy mothers in the Middle Ages, New York-London I995, 259-96; J. A. McNamara, 'The need to give: suffering and female sanctity in the Middle Ages', in R. Blumenfeld-Kosinski and T. Szell (eds), Images of sainthood in medieval Europe, Ithaca-London I99I, I99-22I.

38 Vita, I77, I9I.

${ }^{39}$ For different views see Huneycutt, 'Intercession and the high-medieval queen'; Parsons, 'The queen's intercession'; A. Poulet, 'Capetian women and the regency: the genesis of a vocation', in Parsons, Medieval queenship, 93-I I6; P. Stafford, 'Emma: the powers of the queen in the eleventh century', in Duggan, Queens and queenship, 3-26.

${ }^{40} \mathrm{~J}$. M. Bak, 'Roles and functions of queens in Árpadian and Angevin Hungary (I000-1386 AD.)', in Parsons, Medieval queenship, I3-24, and 'Queens as scapegoats in medieval Hungary', in Duggan, Queens and queenship, 222-33.

41 Klaniczay, Holy rulers, 278-9.

${ }^{42}$ Ibid. $209-32$. 


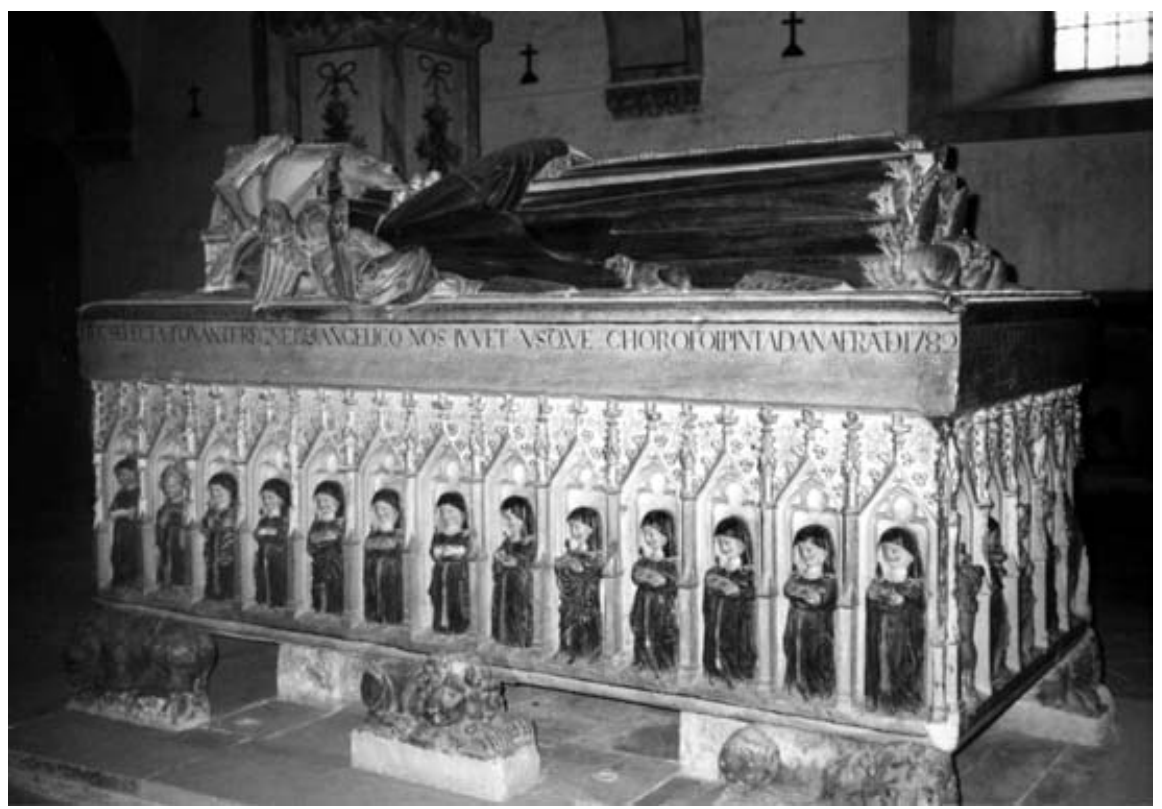

CIona McCleery 2002

Figure 3. Tomb of Isabel of Aragon at Santa Clara, Coimbra: left-hand images from left to right: Francis, Louis of Toulouse, Clare, ten Franciscan nuns.

left-hand side, figures of St Louis of Toulouse, St Clare and St Francis. Isabel herself is dressed as a Franciscan nun but wears a crown, and incorporated into the crucifixion scene at the head are the Aragonese royal arms. It therefore seems that Franciscan and dynastic ideals were woven together in the queen's projection of her self-identity. ${ }^{43}$ Secondly, there is documentary evidence that Isabel venerated her great-aunt. In a codicil of her will of 1327 she founded a hospital near Santa Clara de Coimbra dedicated to her, and Santa Clara itself was dedicated to both Clare and Elizabeth. ${ }^{\mathbf{4 4}}$ Elizabeth's cult was popular in Aragon in the late thirteenth century, ${ }^{45}$ but virtually unknown in Portugal before Isabel arrived in I282, so it would appear that

43 F. Pato de Macedo, 'O túmulo gótico de Santa Clara', in Imagen de la Reina Santa: Santa Isabel, infanta de Aragón y reina de Portugal, Zaragoza I999, ii. 93-I I4.

${ }^{44}$ F. F. Lopes, 'Fundação do mosteiro de Santa Clara de Coimbra: problema de direito medieval', Colectânia de estudos 2nd ser. iv (I953), I66-92 at pp. I73-4, I78; Vasconcelos, Evolução, ii. I9-22, 31.

45 Jaspert, 'Heresy and holiness'; J. Webster, Els Menorets: the Franciscans in the realms of Aragon from St Francis to the Black Death, Toronto 1993, and 'La reina doña Constanza y los hospitales de Barcelona y Valencia', Archivo ibero-americano li (I99I), 375-90. 


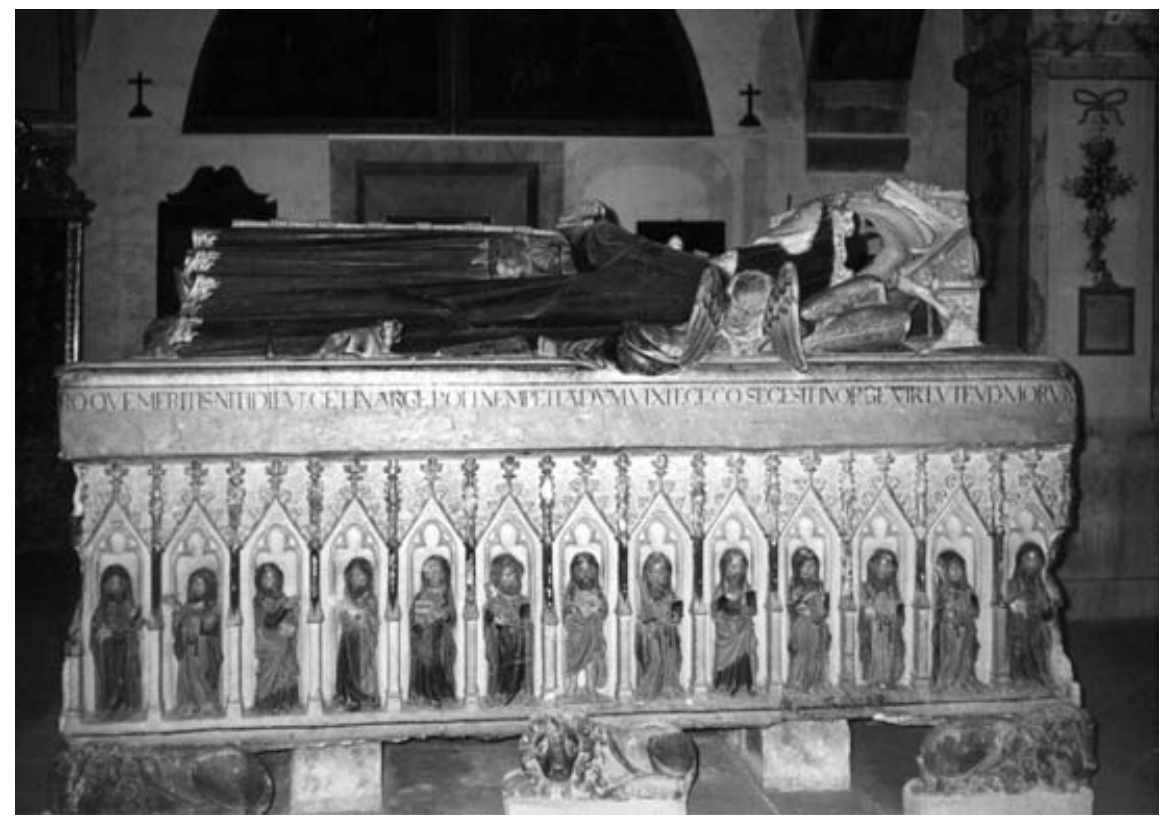

CIona McCleery 2002

Figure 4. Right-hand images: Christ and twelve apostles.

she introduced it into Portugal. ${ }^{46}$ The problem is that Santa Clara was initially founded in the late I270s or early i28os by Mór Dias, a noble woman of Coimbra, sparking off a legal battle with the Augustinian priory of Santa Cruz de Coimbra, the original beneficiary of her wealth. It is not clear when the dedication of the new foundation was decided; its first stone was not formally laid until I286, but a community of women already seems to have been living on the site by then. There is no evidence that Isabel was involved in the foundation until after Mór's death in I302, by which time Santa Cruz had won its case and Isabel had to re-found the nunnery in I3I4. It is possible that Mór Dias founded the nunnery in honour of the new queen and her dynastic saint. Mór's sister, Joana, and brother-in-law, Fernão Fernandes Cogominho, were prominent members of the royal court who would have informed Mór about Isabel's religious preferences. Also, one of the procurators responsible for bringing Isabel to Portugal, João Martins de Soalhães (d. I325), later bishop of Lisbon and finally archbishop of Braga, was

46 Afonso III of Portugal came across the cult of St Elizabeth in France in I24I while in attendance on his aunt Blanche of Castile, but there is no evidence that he brought it home with him: Jean de Joinville, Life of St Louis, in Chronicles of the crusades, trans. M. R. B. Shaw, Harmondsworth i963, I87-8. 


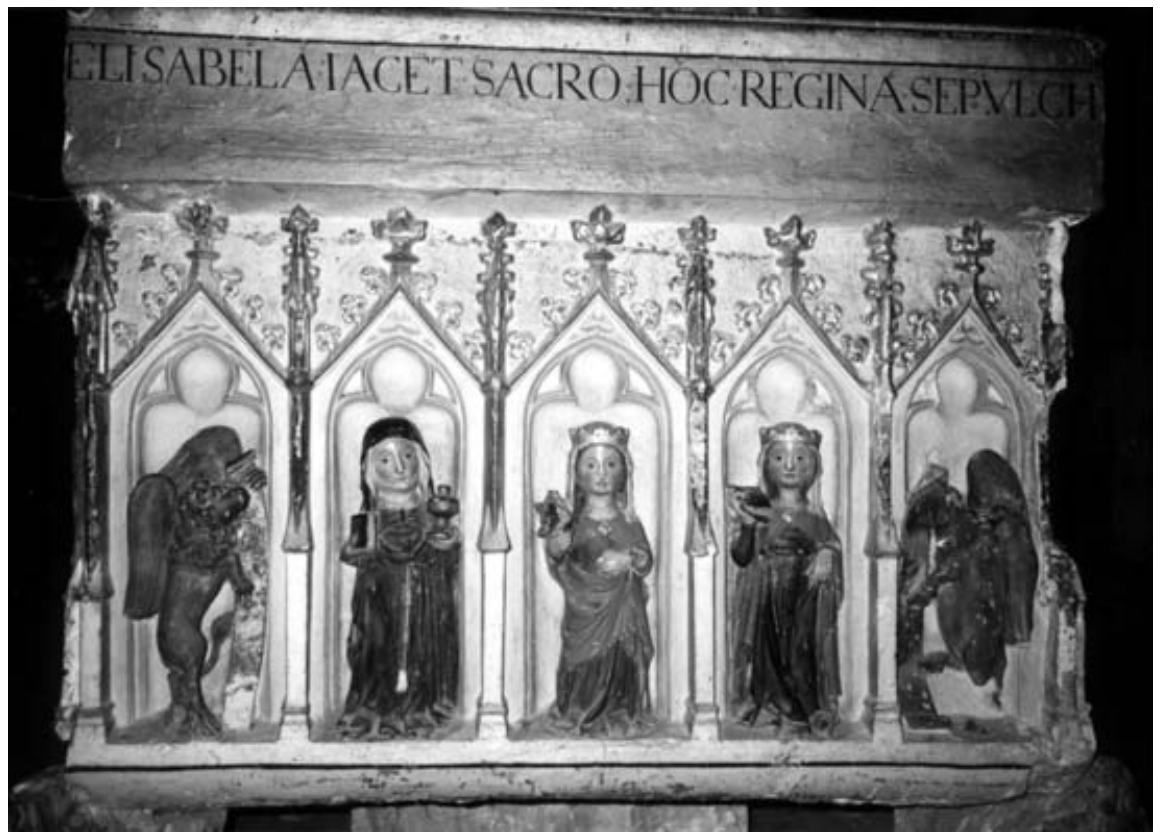

CIona McCleery 2002

Figure 5. Foot of tomb from left to right: Mark's lion, Clare, Catherine, Elizabeth, Luke's ox.

Mór Dias's strongest supporter against the canons of Santa Cruz. ${ }^{47}$ This suggests that future work on Isabel's life and cult should explore the Coimbrense context more deeply. Isabel's period of widowhood spent in Santa Clara is the least studied period of her life, and the flourishing of her cult until the present day depended on local political and religious forces that require further investigation.

As can be seen from the family trees (see Figures 7, 8), it is possible to compare Isabel of Aragon to numerous European queens; however, only a few can be discussed here. Firstly, consider Isabel's Aragonese family. Her mother Constance (d. I30o), founded and lived in a Franciscan nunnery in Sicily after she was widowed, left money in her will to found Franciscan hospitals in Barcelona and Valencia and was eventually buried in the Franciscan habit in

${ }^{47}$ M. T. Monteiro and J. J. Rigaud de Sousa, 'Notas sobre o pleito entre D. Mór Dias, fundadora do convento de Santa Clara de Coimbra, e os cónegos do mosteiro de Santa Cruz (Coimbra)', Estudos medievais i (I98I), 8I-93; A. P. P. Figueira Santos, 'A fundação do mosteiro de Santa Clara de Coimbra: da instituição por D. Mor Dias à intervenção da Rainha Santa Isabel', unpubl. MA diss. Coimbra 2000, 82-I03. 


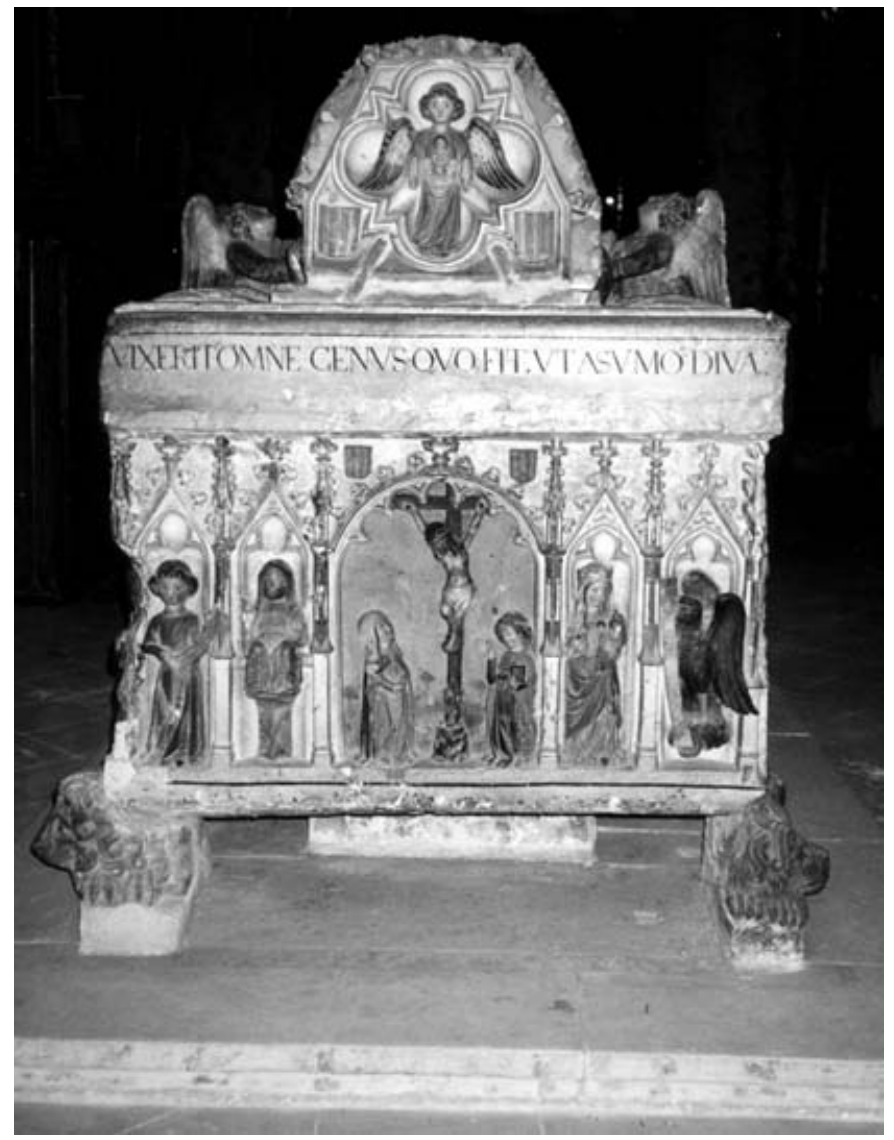

CIona McCleery 2002

Figure 6. Head of tomb from left to right: Matthew, Christ enthroned, crucifixion scene with Aragonese royal arms above on either side, Virgin Mary, John's eagle. Above: Aragonese royal arms flanking angel holding the Christ child.

Barcelona. ${ }^{48}$ Isabel could therefore simply have been imitating her mother. Even though she was quite young when she went to Portugal, her relationship with her birth family remained close. After her mother's death in I300 she wrote to her brother thanking him for sending her a jewel that had belonged to their mother, saying: 'although I do not lack jewels and other things, I very much desired something that my mother had worn'. ${ }^{49}$ Moving further afield, Isabel can be compared to Sancia of Majorca, her

48 Webster, Els Menorets, 94-6, and 'La reina doña Constanza'.

49 Rainha Santa: cartas inéditas, I43. 


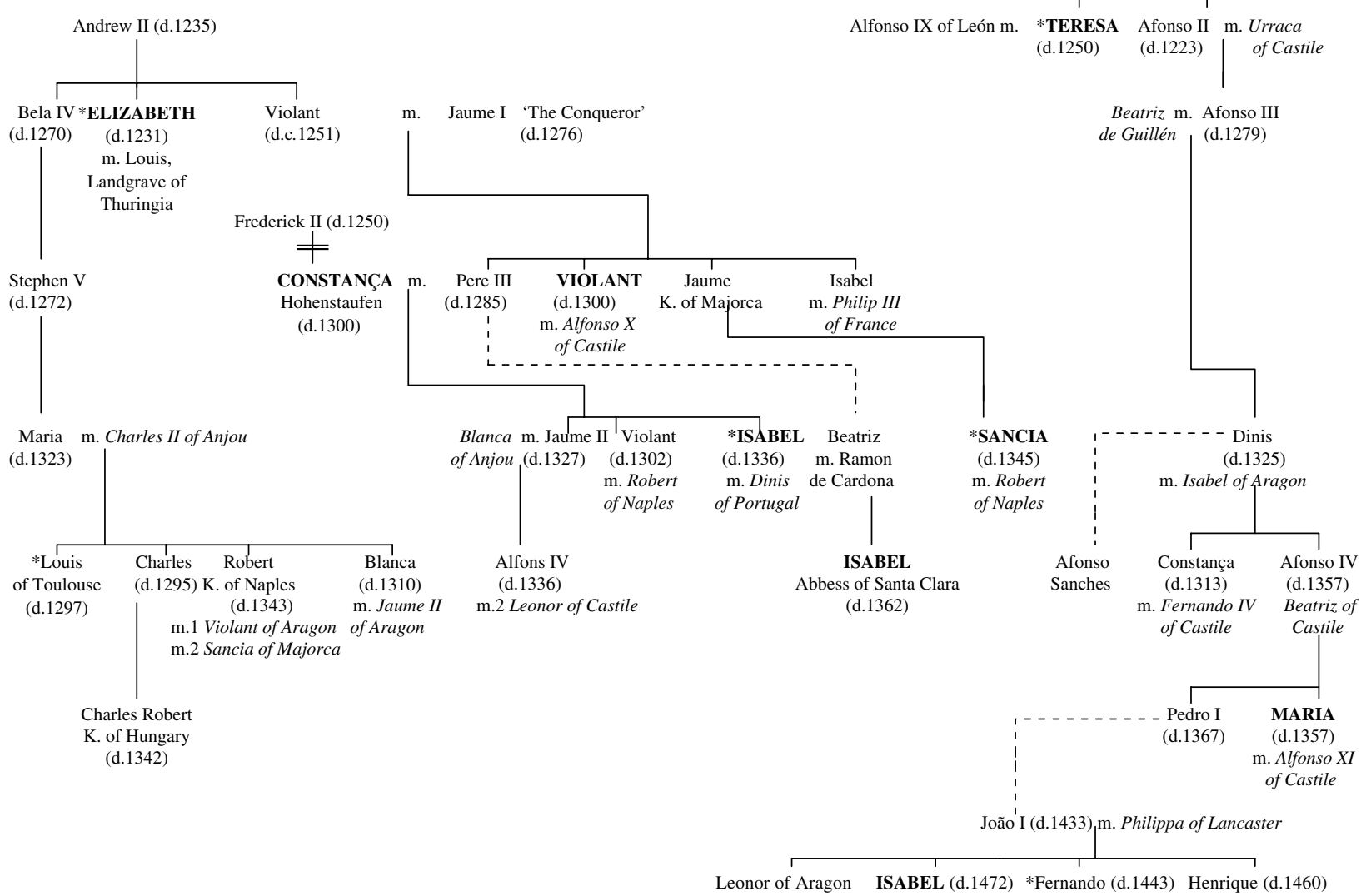

$\begin{array}{ll}* \text { TERESA } & \text { Afonso II m. Urraca } \\ \text { (d.1250) } & \text { (d.1223) of Castile }\end{array}$

Figure 7. The family of Isabel of Aragon: Hungary/Naples, Aragon and Portugal. 

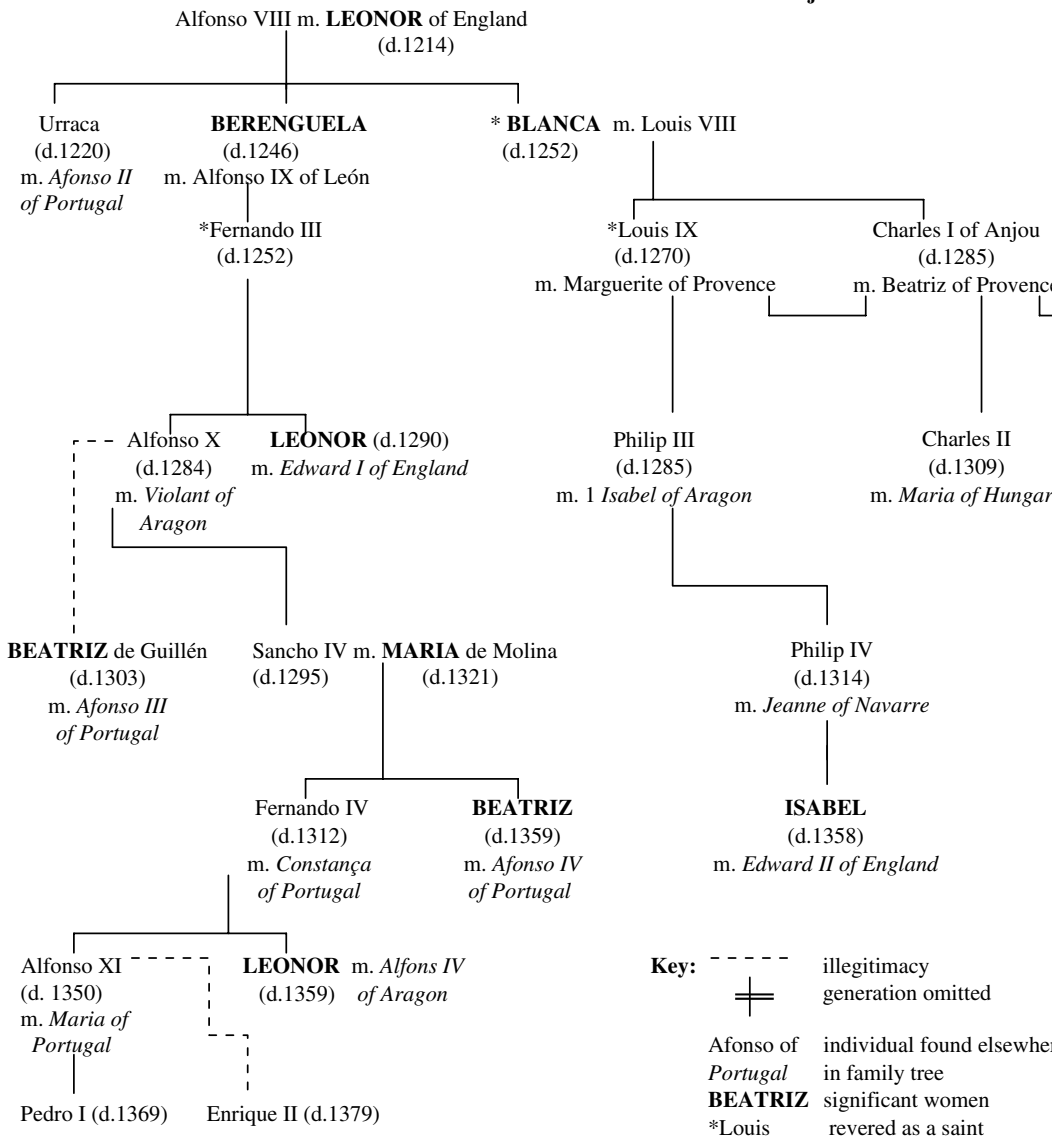

Henry III m. LEONOR of Provence (d.1291)
BEATRIZ significant women

Philip III
(d.1285)

m. 1 Isabel of Aragon maria of Hungary

Figure 8. The family of Isabel of Aragon: Castile, France/Anjou and England. 
first cousin. With her husband, Robert of Naples, Sancia supported the Spiritual Franciscans against the pope and deeply venerated Elizabeth of Hungary as a dynastic saint; both Sancia and Robert were descended from the Hungarian royal family. After Robert's death, Sancia ruled Naples as regent for his grand-daughter Joanna, became a Franciscan nun in I344, and was eventually buried in her own foundation, Santa Chiara of Naples. Joanna later wrote to the pope claiming that Sancia's body had been found incorrupt. No pope could countenance a saint who had worked so hard to oppose papal policy but Joanna's belief that Sancia was a saint may have been shared by others, suggesting another complex relationship between queenship and sainthood. ${ }^{50}$

Turning to Castile, we can compare Isabel to her aunt Violant, wife of Alfonso x (d. I30o), to Isabel's own mother-in-law Beatriz de Guillén (d. I303), Alfonso's illegitimate daughter, and to Violant's daughter-in-law Maria de Molina (d. I32I), wife of Sancho IV. Violant and Beatriz intervened in the civil war of the early I280s between Alfonso X and the future Sancho IV, which is similar to the Portuguese civil war of forty years later. ${ }^{51}$ Maria de Molina (d. I32I) ruled Castile during the minorities of her son Fernando IV and grandson Alfonso XI in the early fourteenth century, and is mentioned several times in Isabel's vita and in her correspondence. ${ }^{52}$ It is to be hoped that future work on Iberian queens will investigate the lives of these women further, revealing the complex political and cultural network that links them together.

Isabel can also be compared to the queens of England. It is not surprising that parallels can be found with the lives of Eleanor of Provence (d. I29I), wife of Henry III (1217-72), or Eleanor of Castile (d. I290), wife of Edward I (1272-I307), since they came from worlds not that far removed from Portugal. ${ }^{53} \mathrm{~A}$ more unexpected comparison can be made with Isabella of France (d. I358), wife of Edward II (I307-27) and Isabel of Aragon's first cousin once removed. Isabella acted as diplomat in negotiations between France and England; became involved in a rebellion in ${ }^{1} 326-7$ that closely resembles the Portuguese civil war of a few years earlier; largely retired from court life after her son Edward III came to power in I330; and eventually chose to be buried in Greyfriars, London, rather than in the more usual Westminster Abbey. However, in contrast to Isabel of Aragon, Isabella of

${ }^{50}$ R. G. Musto, 'Queen Sancia of Naples (I286-I345) and the Spiritual Franciscans', in J. Kirshner and S. F. Wemple (eds), Women of the medieval world, Oxford i985, I79-2I4.

${ }^{51} \mathrm{~J}$. F. O'Callaghan, The learned king: the reign of Alfonso X of Castile, Philadelphia 1993, 266-7. Beatriz returned to Castile at the same time as Isabel arrived in Portugal, thus depriving her of an immediate guide.

${ }^{52}$ Rainha Santa: cartas inéditas, I28-9; Vita, I77, 178, I89, I95; Álvarez Palenzuela, 'Relaciones peninsulares en el siglo de Alcañices (I250-I350)', IO52-64.

${ }^{53}$ J. C. Parsons, Eleanor of Castile: queen and society in thirteenth-century England, New York 1995;

M. Howells, Eleanor of Provence: queenship in thirteenth-century England, Oxford 1998. 
France has gone down in English history as a 'she-wolf' who deposed her husband, connived at his murder, ruled with her lover and was toppled from power by her son. ${ }^{54}$ The differences between the two queens' reputations cannot be explained simply by contrasting political situations, since up to a certain point they behaved in exactly the same way. England and France were long-term rivals as Aragon and Portugal never were so it is likely that this determined the queens' careers from the beginning. However, the relationships between the women and their sons were also crucial. Afonso IV of Portugal, a mature married man, could have been disinherited by Dinis if it had not been for his mother's help, whereas the teenage Edward III's position in relation to his mother and her co-conspirator Roger Mortimer was more ambiguous. ${ }^{55}$ Further comparison between these two queens would illuminate the processes behind the construction of royal power and reputation.

Teresa Vann, in her study of Castilian queenship, argues that thirteenthcentury queens remained closely tied to the interests of their kin and that their power depended on their own family background. ${ }^{\mathbf{5}}{ }^{\mathbf{6}}$ This is certainly borne out by the careers of all the queens described here. Isabel of Aragon's letters indicate that her ties to Aragon were of paramount importance, and that her Aragonese identity underpinned her power in Portugal. Her marriage to Dinis can be explained by the need to counterbalance Castilian aggression in the peninsula, and her ability to intercede with her husband was based on the prestige of the well-established house of Barcelona rather than on the dubious power granted by her husband's dynasty. After all, when Dinis and Isabel married he was the excommunicate son of a bigamous usurper. This being the case, it is likely that models of queenly behaviour were learned within the birth family, probably passed down from mother to daughter. Indeed, the Siete partidas of Alfonso x emphasise the queen's responsibility for the education of her daughters. Even where children were extremely small when they left home - Isabel became responsible for her daughter-in-law when she was four-mothers-in-law, often relatives themselves, were effective substitutes. Very few of the women discussed here came to be viewed as saints, but they all behaved in remarkably similar ways as queens and this must be because there was a standard form of behaviour that they learned as children.

54 S. Menache, 'Isabelle of France, queen of England: a reconsideration', Fournal of Medieval History x (1984), I07-24; J. C. Parsons, 'The intercessional patronage of Queens Margaret and Isabella of France', Thirteenth-century England vi (1995), I45-56.

${ }_{55}$ M. Bennett, 'Isabelle of France, Anglo-French diplomacy and cultural exchange in the late I350s', in J. S. Bothwell (ed.), The age of Edward III, York 200I, 215-25, argues convincingly that Isabella was not imprisoned for the rest of her life and remained politically and culturally active.

56 Vann, 'Medieval Castilian queenship', I46-7. 
We do not know for certain how models of queenship were transmitted to daughters. Was it done through imitation and personal example, or through formal training and textual guidance? It is possible that intercessory rituals undergone by new English queens may have been training sessions, and there are traces of a similar episode placed early in Isabel's career in the vita. ${ }^{57}$ Pondering this possible textual example, leads one to consider what may have been behind the writing of Isabel of Aragon's vita. The saint whom Isabel most closely resembles is not Elizabeth of Hungary, but Margaret (d. I093), Anglo-Saxon wife of Malcolm Canmore of Scotland. Margaret's vita, usually attributed to her confessor Turgot, prior of Durham and later bishop of St Andrews, is strikingly similar to Isabel's. Both works describe close links to religious houses whose fortunes are tied up in the queen's reputation (Dunfermline Abbey in Margaret's case), concern with children, similar liturgical routines, very few demeaning acts of piety and examples of secret acts of charity. Ironically there is even a link to Hungary since Margaret was born there ${ }^{58}$ Spiritually Isabel has far more in common with Margaret than she has with the mystical saints of the fourteenth century; hers is a much more old-fashioned type of sainthood. It is also a more old-fashioned type of queenship. The political situations of Margaret and Isabel were quite similar despite the fact that they lived three centuries apart. Scotland and Portugal were both relatively new small kingdoms undergoing consolidation, and neither had crowned or anointed kings. They each had big awkward neighbours and more or less integrated minority groups. In this respect Isabel fits the model of conversion queen put forward by Jo Ann MacNamara. Fourteenth-century Portugal, with its memories of Moorish conquest and interests in North Africa and the Atlantic, sometimes compares less well with contemporary France or England than with medieval kingdoms developing in frontier zones such as Scotland in the eleventh century, and indeed Hungary through to the thirteenth. ${ }^{59}$

There is no need for a direct link between the vitae of Isabel and Margaret; it is another example of how models of queenship can transcend time and space. The important point is that the life of St Margaret seems to have been written as a guide to queenly behaviour for her daughter Matilda (d. III8), the wife of Henry I of England. ${ }^{60}$ This

${ }^{57}$ P. Strohm, 'Queens as intercessors', in P. Strohm, Hochon's arrow: the social imagination of fourteenth-century texts, Princeton 1992, 95-II9 at pp. I05-6; Vita, I78. According to the vita Isabel intervened in a quarrel between Dinis and his brother Afonso at an early stage in her queenly career.

${ }^{58}$ L. L. Huneycutt, Matilda of Scotland: a study in medieval queenship, Woodbridge 2003, I0-16, I6I-78, and 'Public lives, private ties: royal mothers in England and Scotland, I070-I204', in Parsons and Wheeler, Medieval mothering, 295-3II; V. Wall, 'Queen Margaret of Scotland (I070-I093): burying the past, enshrining the future', in Duggan, Queens and queenship, $27-38$.

${ }^{59}$ Klaniczay, Supernatural power, 79-94.

${ }^{60}$ Huneycutt, Matilda of Scotland, ro. 
suggests that the author of Isabel's vita may also have had a didactic purpose in writing the work. In fact the vita may have been aimed at three members of Isabel's family: her daughter-in-law Beatriz (d. I359), and her grand-daughters Maria (d. I357), queen of Castile, and Leonor (d. I359), queen of Aragon. All three feature prominently in the vita; the author reminds the reader that they were left jewelled crowns in Isabel's will, thus presenting an image of one queen passing on her wealth and prestige to others. ${ }^{61}$ In Beatriz's case, she was the only person to play a role similar to Isabel's within Santa Clara, serving the nuns in their new refectory. She was also present when Isabel had a vision of Christ and the Virgin Mary just before her death. ${ }^{62}$

Examining the careers of these younger women may reveal whether they followed the model of queenship presented by Isabel. Leonor, queen of Alfons IV of Aragon, was widowed early. She quarrelled with her stepson Pere IV over the rights of her own sons, and became involved in a war between Aragon and Castile. According to chroniclers, her nephew Pedro I of Castile eventually had her killed. ${ }^{63}$ Leonor's character, as represented in the chronicles, is not flattering, and in this she compares well with Isabella of France. Her cousin Maria, on the other hand, was lauded by chroniclers, although she did not behave very differently. Her husband Alfonso XI of Castile preferred his mistress Leonor de Guzman and favoured his children by her. Like Isabel, Maria apparently accepted her husband's affair but supported the interests of her own son, Pedro I. According to chroniclers, she also interceded politically between her husband and her father persuading them to ally against Morocco, an alliance that resulted in a Christian victory at Salado in I340. One of the last great encounters of the Reconquista, this battle may have provided the background to the writing of Isabel's vita as it glorifies such alliances and downplays the more usual competitiveness of the Iberian kingdoms. Reality of course was much more interesting. It was Maria who ordered the execution of her rival Leonor in I35I, and one of Alfonso's illegitimate sons, Enrique II, deposed Maria's son Pedro I in I369, thus offering the opposite yet always possible outcome of the kind of conflict in which Isabel and her son had engaged. ${ }^{64}$

Maria's mother Beatriz may also have tried to behave like her predecessor during a major conflict between her son Pedro and his father caused by the murder of Pedro's concubine, Inês de Castro, at his father's orders in I355. Beatriz also supported the Franciscan order and like

61 Vita, I79, I86, I92; Vasconcelos, Evolução, ii. I3-I4. $\quad{ }^{62}$ Vita, I88, I9I.

63 Pere III of Catalonia (Pedro IV of Aragon), Chronicle, trans. M. Hillgarth with introduction and notes by J. N. Hillgarth, Toronto I980, ii. 494. See also T. N. Bisson, The medieval crown of Aragon, Oxford I99I, I04-20.

${ }_{64}$ Rui de Pina, Crónicas, 436-8; C. Estow, Pedro the Cruel of Castile, 1350-1369, Leiden I995, especially ch. vi. 
her mother-in-law was buried in the Franciscan habit. However, the comparison ends there as she and her husband were buried in Lisbon Cathedral. ${ }^{65}$ This may have been a blow to the author's hopes, since he or she no doubt had hoped to encourage imitation of all aspects of the old queen's behaviour, including burial in her foundation. Unfortunately, Portuguese monarchs still preferred Cistercian houses or chose burial in the cathedral of a city that had long since superseded Coimbra in importance. Hopes may initially have been high for Santa Clara because Inês de Castro, murdered in Coimbra, was at first buried there, but after six years Pedro removed her to Cistercian Alcobaça. ${ }^{\mathbf{6 6}}$ The abbess of Santa Clara who arranged the initial burial - none other than Isabel de Cardona, the old queen's niece - must have been bitterly disappointed at this. Her possible authorship of the vita could stem from natural interest in the careers of her royal cousins and the fact that she had most to gain from Isabel's cult in the long-term. ${ }^{67}$ By writing the vita, Isabel de Cardona may have hoped to secure the future glory of both her family and her nunnery by extolling the virtues of the Rainha Santa. Giving advice in the form of a saint's life simply reinforced the message. There was no need for Isabel's female descendants to aspire to sainthood; it would be enough if they followed the advice given and became model queens.

Isabel of Aragon may have been a model queen for the women of her immediate family. Did she continue to influence subsequent generations, or was she just remembered as an ancestral saint? In I428 Duarte, son and heir of João I of Portugal, married Leonor, daughter of Fernando I of Aragon. The ceremony took place in Santa Clara de Coimbra near Isabel's tomb and Duarte's brother, Henry 'the Navigator', explained that for Leonor 'it was just as if she had married from the house of Queen Isabel who also came from Aragon. Every one of us thought that this matter had worked out so well because of the holiness of the said Queen Isabel from whose house it had started ' ${ }^{68}$ Significantly, Leonor was the first Aragonese princess to marry a Portuguese crown prince since Isabel did so nearly I50 years before, and for much the same reason: restoring the balance of power against Castile, so this method of settling Iberian conflict through marriage created a link between

${ }^{65}$ See Beatriz's will of 1358 in A. Caetano de Sousa, Provas da história genealógica da casa real portuguesa, Coimbra I946, i. $343-55$.

${ }^{66}$ Vasconcelos, Evolução, i. 229-31. For the Inês de Castro episode in general see A. H. de Oliveira Marques, Portugal na crise dos séculos XIV e XV, Lisbon I986, 504-5, and Rui de Pina, Crónicas, 464-9.

${ }^{67}$ Isabel de Cardona's relationship with the royal family continued after her aunt's death; she received $£ 300$ in Beatriz's will: Caetano de Sousa, Provas, 350.

${ }^{68}$ P. Russell, Prince Henry 'the Navigator': a life, New Haven-London 2000, 365-9. For background see T. F. Ruiz, 'Festivités, couleurs et symbols du pouvoir en Castille au Xve siècle: les celebrations de mai I428', Annales ESC iii (I99I), 52 I-46. 
Isabel and Leonor that had more to do with queenship than sainthood. Moving on to the mid-sixteenth century, the short Isabelline vita dedicated to Caterina, Spanish wife of João III, emphasises not Coimbra but the town of Alenquer: a place 'to which the queens of these kingdoms were always much devoted'. ${ }^{69}$ Alenquer had been part of the dower of Portuguese queens since the mid-thirteenth century and both Isabel and Caterina - foreign queens establishing themselves on a new political scene - developed the town as a power base. Dinis imprisoned Isabel in Alenquer during the civil war as her use of this stronghold made her a threat in his eyes. Thus Caterina and Isabel were also linked across the centuries by their queenship rather than by any aspirations to sainthood.

Isabel not only influenced her female descendants. João I, an illegitimate son who usurped the throne in $\mathrm{I}_{3} 85$, was trying to establish a new dynasty, so it is likely that the cult of his Aragonese great-grandmother represented legitimacy, continuity and prestige, much as the alliance with Aragon sealed by the marriage of his son represented stability. Isabel probably also had a legitimising function in the eyes of the Habsburg rulers of a united Spain and Portugal who eventually secured her canonisation in the seventeenth century, and of the Braganzas who visited Isabel's tomb until the Portuguese monarchy was overthrown in the early twentieth century. ${ }^{70}$ For these monarchs, the figure of the Rainha Santa was tied up in their understanding of their royal authority. She was more queen than saint to them. Those people who saw Isabel as saint first and foremost were the local people of Coimbra, so it is ironic that they still venerate her today, while the idea of a Portuguese royal family is a fading memory.

Isabel was not a model saint in that she does not compare well to the female saints of the late Middle Ages, including those of the royal house of Hungary. This does not mean that she was not influenced by the example of her aunt, Elizabeth of Hungary, but hers was a cult that linked Isabel as much to her home in Aragon as to the Franciscan order. The original foundation of Santa Clara de Coimbra by the Portuguese was in homage to the new queen's origins rather than real appreciation of her saintly lineage; the survival of the queen's cult in Santa Clara today is a reflection of local religious and political influences. Isabel is a model queen in two respects: first in that she conforms to a model of good queenship, including religious and political behaviours, as practised by her mother and numerous other royal women both of her own time and earlier. It seems likely that queenship was taught within families, effective even in cases where mother and daughter were separated early on, and the interests of a queen's birth family dictated the nature of her power and prestige. Isabel is a model queen in a second respect in that she served as 
692 IONA MGCLEERY

a model for future queens of her dynasty, and indeed one of the functions of the vita may have been to guide these women. Isabel was obviously remembered as a family saint, but the fact that she had been a queen resonates through time. It is not for nothing that she is still called the Rainha Santa. 